\title{
Salinity and Low Phosphorus Differentially Affect Shoot and Root Traits in Two Wheat Cultivars with Contrasting Tolerance to Salt
}

\author{
Ghulam Abbas ${ }^{1,2, *}$, Yinglong Chen ${ }^{2,3} \mathbb{B}^{(}$, Faisal Younus Khan ${ }^{2,4}$, Yupeng Feng ${ }^{2,5}$ (D), \\ Jairo A. Palta ${ }^{2,6}$ and Kadambot H. M. Siddique ${ }^{2}$ \\ 1 Department of Environmental Sciences, COMSATS University Islamabad, \\ Vehari-Campus, Vehari-61100, Pakistan \\ 2 The UWA Institute of Agriculture, and School of Agriculture and Environment, \\ The University of Western Australia, LB 5005, Perth WA 6001, Australia \\ 3 State Key Laboratory of Soil Erosion and Dryland Farming on the Loess Plateau, Northwest A\&F University, \\ and Chinese Academy of Sciences, Yangling 712100, Shaanxi, China \\ 4 Department of Agricultural Sciences, University of Haripur, Khyber Pakhtunkhwa 22620, Pakistan \\ 5 College of Agronomy, China Agricultural University, Beijing 100193, China \\ 6 CSIRO Agriculture \& Food, Private Bag No. 5, Wembley, WA 6913, Australia \\ * Correspondence: ghulamabbas@ciitvehari.edu.pk; Tel.:+923-006-116-275
}

Received: 9 July 2018; Accepted: 17 August 2018; Published: 20 August 2018

\begin{abstract}
Soil salinity and phosphorus (P) deficiency both have adverse effects on crop growth and productivity, but the interaction of soil salinity and P deficiency is not well known. Two P-inefficient wheat cultivars, Janz (salinity-tolerant) and Jandaroi (salinity-sensitive), grown in soil in rhizoboxes, were treated with either $100 \mu \mathrm{M} \mathrm{P}$ (control), $100 \mathrm{mM} \mathrm{NaCl}$ (saline stress), $10 \mu \mathrm{M}$ P (low P stress), or both $\mathrm{NaCl}$ and low $\mathrm{P}$ (combined stress), from 10 days after sowing (DAS) until harvest at 40 DAS. Significant reductions in leaf area, shoot and root biomass, tissue water and chlorophyll contents, gas exchange, and $\mathrm{K}^{+}$and $\mathrm{P}$ acquisition at harvest were observed in the three treatments. The reduction was greater for low $\mathrm{P}$ supply than for salinity alone, but their interaction was not additive. The detrimental effects on root growth became apparent 10 days earlier in Jandaroi compared to Janz. Root length, root number, root length densities, and root number densities were higher in the upper $10 \mathrm{~cm}$ soil layer than in the lower layers for both cultivars. This study demonstrated that $10 \mu \mathrm{M} P$ is more detrimental than $100 \mathrm{mM} \mathrm{NaCl}$ for shoot and root growth of both wheat cultivars irrespective of their difference in salinity tolerance.
\end{abstract}

Keywords: leaf gas exchange; P availability; root mapping; salt tolerance; root length density

\section{Introduction}

More than $6 \%$ of the world's land and $20 \%$ of its irrigated areas are facing salinity threats $[1,2]$. Soil salinity is a major abiotic stress that limits crop growth and productivity [3,4]. Soil salinity causes osmotic stress [5] and ionic imbalance [4,6], and reduces gas exchange [7,8], tissue water, and chlorophyll contents [9], which reduce shoot and root growth [3,10,11]. The extent of the damage caused by salinity depends on the plant's developmental stage, duration of the salt stress, the amount and type of salt in the growth medium, and the crop cultivar/genotype [7,8].

Plants have developed various mechanisms to overcome both the osmotic and ionic effects of salinity [1,3]. Salt-tolerant plants have better osmotic adjustment capabilities, enabling them to uptake water under high salinity levels [5]. Ionic toxicity is mitigated by the restricted uptake of toxic ions or cellular compartmentation into vacuoles or older tissues [12]. Moreover, maintaining a higher $\mathrm{K}^{+} / \mathrm{Na}^{+}$ 
ratio in the cytosol is directly related to higher salt tolerance and better growth in plants facing salinity stress $[5,6]$.

Phosphorus $(\mathrm{P})$ is a vital macronutrient for plant growth due to its involvement in photosynthesis, respiration, nucleic acid synthesis, enzyme activities, membrane synthesis and stability, carbohydrate metabolism, signalling, and redox reactions $[13,14]$. Low soil P is another environmental factor that limits agricultural productivity. About $30-40 \%$ of the world's arable lands have very low productivity due to $\mathrm{P}$ deficiency [15]. To deal with $\mathrm{P}$ deficiency, plants have evolved various adaptive mechanisms including increased root length, lateral root density, root hair number, and root-to-shoot ratio, rhizosphere acidification, proper placement of roots in soil, and the formation of finer and longer roots $[16,17]$.

Various inorganic P fertilizers are applied to soils to increase their P levels. Plants are unable to uptake much of the applied $\mathrm{P}$ due to its adsorption and fixation in the soil $[17,18]$. In acidic soils, P solubility is reduced due to the formation of sparingly soluble compounds with iron and aluminium, and in alkaline calcareous soils, poorly soluble complexes with calcium are formed $[17,19]$. The solubility of $\mathrm{P}$ is greatly reduced in salt-affected soils due to high $\mathrm{Na}$ concentration and soil $\mathrm{pH}$ [20]. Hence, the plants growing on these soils concurrently face salinity and P deficiency $[13,20]$. Accordingly, studies on lettuce [21] and spinach [22] showed that soil salinity reduced P concentrations in all plant tissues. On the other hand, the findings of $[13,23]$ indicated that shoot and root P concentrations increased in barley grass and cultivated barley genotypes in response to salinity. It has also been reported that $\mathrm{P}$ supply affects $\mathrm{Na}$ transport within plants, and ultimately affects the salt tolerance of crops $[9,24]$. So, the interaction of $\mathrm{P}$ supply and salinity seems to have great practical implications for increasing crop production on salt-affected soils. However, information on the interaction of salinity and low $\mathrm{P}$ is limited and without consensus [25], and it needs further investigation.

Wheat is moderately tolerant to salinity [26], and its growth and physiological responses to salinity stress have been extensively studied $[1,6,7,11,27]$. However, the morpho-physiological responses of wheat to the combined effects of salinity and low $\mathrm{P}$ have not been well understood. The main objectives of this study were to: (i) explore the effects of salinity and low P on the growth, physiological, and ionic relations, and to (ii) examine the changes in root growth and proliferation with time and soil depth in two wheat cultivars differing in salinity tolerance but having similar P efficiencies. To address these objectives, we used salinity-tolerant bread wheat (Triticum aestivum L.) cultivar Janz, which is P-inefficient [28-30] and salinity-sensitive durum wheat (Triticum turgidum L.) cultivar Jandaroi, which is also P-inefficient $[31,32]$ We hypothesized that wheat cultivars would respond differently to salinity and low $\mathrm{P}$ interaction, and the combined stress of low $\mathrm{P}$ and salinity would be more detrimental on these attributes than their individual effects.

\section{Materials and Methods}

\subsection{Plant Material and Growth Conditions}

The Australian bread wheat (Triticum aestivum L.) cultivar Janz (released in 1989, tolerant to soil salinity) and the durum wheat (Triticum turgidum L.) cultivar Jandaroi (released in 2007, sensitive to soil salinity) were selected for the study, based on their differences in tolerance to soil salinity and their similar phenological development [31,33,34]. Both cultivars were grown in freely draining rhizoboxes (40 cm length $\times 5 \mathrm{~cm}$ width, $60 \mathrm{~cm}$ depth) filled with a local, coarse sandy soil. A black Polyvinyl chloride sheet was used to cover the acrylic glass wall of each rhizobox to protect the roots from direct sunlight exposure. The boxes were placed at a $30^{\circ}$ angle on steel stands to facilitate root growth towards the acrylic glass side $[30,35]$. The $30^{\circ}$ angle inclination is ideal for handling and mapping the root system when seeds are sown close to the acrylic glass wall [36,37]. There were two rhizoboxes on each steel stand placed on glasshouse benches.

The soil used in this experiment had the following properties: $\mathrm{pH} 6.7\left(\mathrm{H}_{2} \mathrm{O}\right)$ and $6.0\left(\mathrm{CaCl}_{2}\right)$, electrical conductivity $0.032 \mathrm{dS} \mathrm{m}^{-1}$, organic carbon $2.0 \mathrm{~g} \mathrm{~kg}^{-1}$, and nitrate-N, ammonium-N, Colwell 
$\mathrm{P}$ and Colwell $\mathrm{K}$ were 1.0, 1.0, 3.0, and $27 \mu \mathrm{g} \mathrm{g}^{-1}$, respectively. The total $\mathrm{N}$ may be one to two orders of magnitude higher than the measured nitrate and ammonium levels. However, a high fraction of this $\mathrm{N}$ may be in recalcitrant forms that are not available to the plants. Each rhizobox was filled with soil to a bulk density of $1.53 \mathrm{~g} \mathrm{~cm}^{-3}$. Three pre-germinated seeds of each cultivar were sown at a depth of $2 \mathrm{~cm}$ in rows very close to the acrylic glass wall of each rhizobox corresponding to the field sowing density of 150 plants $\mathrm{m}^{-2}$. After sowing on 17 June 2016, plants were provided with $30 \mathrm{~mL} \mathrm{a}$ low-concentration nutrient solution on each alternate day. The solution was the same as the one used by [16] with the P concentration modified. The solution contained (in $\mu \mathrm{M})$ : $\mathrm{N}(1000), \mathrm{K}(1220), \mathrm{Ca}(600)$, $\mathrm{S}$ (812), Mg (200), Zn (0.75), Cu (0.2), B (5), Mn (0.75), Mo (0.03), Co (0.2), and Fe (20). Two levels of P $(10$ and $100 \mu \mathrm{M})$ were applied as low and optimal P treatments, respectively. In the low P treatment, potassium compensation was provided by adding a supplementary amount of $\mathrm{K}_{2} \mathrm{SO}_{4}$, in order to maintain the same $\mathrm{K}$ concentrations in all treatments. For the $100 \mathrm{mM}$ salinity treatment, $\mathrm{NaCl}$ salt was added to a nutrient solution containing an optimal $\mathrm{P}$ concentration. The control treatment had an optimal P concentration but without salinity.

The experiment was conducted in a temperature-controlled glasshouse at The University of Western Australia, Perth, Australia $\left(31^{\circ} 93^{\prime} \mathrm{S}, 115^{\circ} 83^{\prime} \mathrm{E}\right)$ with a mean relative humidity of $65-70 \%$, and a day/night temperature of $25 / 20^{\circ} \mathrm{C}$. The glasshouse received natural daylight (photoperiod) for 11.5 to $12.5 \mathrm{~h}$ during the study. The average maximum photosynthetic photon flux density (PPFD) of plants was $951 \pm 21 \mu \mathrm{mol} \mathrm{m}{ }^{-2} \mathrm{~s}^{-1}$ at 13:00 h. The salinity and low P treatments commenced at the two-leaf stage (10 days after sowing, DAS). Plants within each treatment were supplied with $50 \mathrm{~mL}$ of the relevant nutrient solutions (control, saline, low P, saline + low P) on a daily basis until harvest. The rhizoboxes were randomly rearranged each week to minimize environmental impacts. A completely randomized design comprising two wheat cultivars and four treatments (control, saline, low $\mathrm{P}$, saline + low $\mathrm{P}$ ) with three replications (rhizoboxes) was used. The experiment was assessed at 40 DAS.

\subsection{Gas Exchange and Chlorophyll Content}

Stomatal conductance (gs), leaf net photosynthetic rate (A), and transpiration rate (E) were measured one day before harvest (i.e., 39 DAS) between 10:00 to 14:00 $\mathrm{h}$ on the second fully expanded leaf from the top using a LI-6400 Portable Photosynthesis System (LI-COR, Lincoln, NE, USA). The measurement conditions were: ambient $\mathrm{CO}_{2}$ concentration $372 \mathrm{mmol} \mathrm{mol}^{-1}$, ambient pressure $99.0 \mathrm{kPa}$, average water vapour pressure in the chamber $3.45 \mathrm{kPa}$, air flow per unit leaf area $205.5 \mathrm{~mol} \mathrm{~m}^{-2} \mathrm{~s}^{-1}$ and maximum photosynthetically active radiations (PAR) up to $1300 \mathrm{mmol} \mathrm{m} \mathrm{m} \mathrm{s}^{-1}$. The chlorophyll content index of the same leaf was measured with SPAD 502 plus chlorophyll meter (Spectrum Technologies, Aurora, IL, USA).

\subsection{Shoot Traits and Nutrients}

Shoot traits such as shoot length, leaf area (LA), tissue water content, and shoot biomass were measured at harvest. Shoot length was measured with a ruler, and LA was measured with a portable leaf area meter (LI-3000, LI-COR Biosciences, Lincoln, NE, USA). Tissue water content (TWC) of the same leaf was measured using the following equation described by [9]:

$$
\mathrm{TWC}=(\mathrm{FW}-\mathrm{DW}) / \mathrm{DW}
$$

where, FW is leaf fresh weight obtained immediately after harvest, and DW is leaf dry weight obtained after drying the leaves at $70{ }^{\circ} \mathrm{C}$ to a constant weight.

All of the plants in each rhizobox were harvested as a single replicate. The shoots were cut at the crown level, and shoot dry weights were recorded after oven drying at $70{ }^{\circ} \mathrm{C}$ for $48 \mathrm{~h}$. Plant samples were digested in di-acid (nitric acid and perchloric acid) as described by [38]. The digest was used to measure the concentrations of $\mathrm{Na}^{+}, \mathrm{K}^{+}$, and $\mathrm{P}$ in the shoot and root samples. 


\subsection{Root Growth}

From the two-leaf stage (10 DAS) until harvest (40 DAS), root growth was traced onto plastic film at 10-day intervals. On each occasion, the growth of new visible roots was traced onto transparent plastic film using a permanent water proof pen. Root growth was also marked on the glass panel each time to distinguish the new, emerging roots. The transparent films were scanned at 600 pixels with a portable scanner (Jenkins PS4100; East Bentleigh, Melbourne, Australia). The root images were analysed for root length and number using WinRHIZO (2008 Pro, Regent Instruments, Québec, QC, Canada).

\subsection{Root Traits at Harvest}

At harvest, the acrylic glass wall of each rhizobox was removed and the soil was divided into six 10-cm sections [36]. The soil of each section was washed through a sieve to recover the roots. Root subsamples were placed in plastic bags and stored at $4{ }^{\circ} \mathrm{C}$ until scanning. The roots were placed in a glass tray and scanned at 400 pixels per mm [39] using a desktop scanner (Epson Expression Scan 1680, Epson America Inc., Long Beach, CA, USA). The obtained images were analysed for root length and root number using WinRHIZO 2008 (model Pro, version 2, Regent Instruments, Québec, QC, Canada) computer software. Root length density (RLD) and root number density (RND) were calculated by dividing the root length and root number of each section by the volume of that section $[16,30]$. Root samples were then oven dried at $70{ }^{\circ} \mathrm{C}$ for $48 \mathrm{~h}$ and the dry weights were recorded. Root length was divided by root dry weight to obtain the specific root length.

\subsection{Statistical Analysis}

All the data were analysed using statistical software package "Statistix 8.1" in a completely randomized design. One-way analysis of variance (ANOVA) was performed as described by [40]. The least significant difference (LSD) test at $5 \%$ significance level and standard errors of the mean were used for further comparison of the treatments.

\section{Results}

\subsection{Plant Growth and Shoot Traits}

Both wheat cultivars were at the two-leaf stage by 10 DAS and they had no emerged tillers at the end of the experiment (40 DAS), indicating similar phenology. The effects of the salinity and low $\mathrm{P}$ treatments significantly affected shoot length in both cultivars (Table $1, p \leq 0.001$ ). The three treatments (salinity, low $\mathrm{P}$, salinity + low P) significantly reduced shoot length in the salt-sensitive cultivar (Jandaroi) to similar values. The salinity treatment had no effect on shoot length in the salt-tolerant cultivar (Janz), but the low P and salinity + low P treatments significantly reduced the shoot length by about one-third, compared to the control. Leaf areas of both cultivars were significantly $(p \leq 0.001)$ reduced in all three treatments, and more so in the low P treatments than the salinity treatment (Table 1). 
Table 1. Effects of salinity, low phosphorus (P) supply and their interaction on shoot length (SL, cm), leaf area $\left(\mathrm{LA}, \mathrm{cm}^{2}\right)$, shoot dry weight (SDW, $\mathrm{g}$ plant ${ }^{-1}$ ), root dry weight (RDW, g plant ${ }^{-1}$ ), shoot:root dry weight ratio (RDW:SDW), chlorophyll content index (CCI, SPAD value) and tissue water content (TWC, $\mathrm{mL} \mathrm{g}^{-1} \mathrm{DW}$ ) of salt-tolerant (Janz) and salt-sensitive (Jandaroi) wheat cultivars.

\begin{tabular}{ccccc}
\hline Janz & Control & Salinity & Low P & Salinity + Low P \\
\hline SL & $22.2 \pm 0.93 \mathrm{a}$ & $19.7 \pm 1.0 \mathrm{a}$ & $14.8 \pm 1.59 \mathrm{~b}$ & $13.7 \pm 0.33 \mathrm{~b}$ \\
LA & $575.8 \pm 19 \mathrm{a}$ & $323.8 \pm 18 \mathrm{~b}$ & $177.7 \pm 28.5 \mathrm{c}$ & $162.2 \pm 14.4 \mathrm{c}$ \\
SDW & $0.132 \pm 0.01 \mathrm{a}$ & $0.073 \pm 0.003 \mathrm{~b}$ & $0.029 \pm 0.002 \mathrm{c}$ & $0.026 \pm 0.006 \mathrm{c}$ \\
RDW & $0.166 \pm 0.013 \mathrm{a}$ & $0.087 \pm 0.0104 \mathrm{~b}$ & $0.044 \pm 0.006 \mathrm{c}$ & $0.041 \pm 0.003 \mathrm{c}$ \\
RDW: SDW & $1.25 \pm 0.06 \mathrm{~b}$ & $1.18 \pm 0.05 \mathrm{~b}$ & $1.52 \pm 0.05 \mathrm{a}$ & $1.56 \pm 0.04 \mathrm{a}$ \\
CCI & $38 \pm 2.88 \mathrm{a}$ & $36.4 \pm 2.28 \mathrm{a}$ & $25.6 \pm 1.04 \mathrm{~b}$ & $24 \pm 1.82 \mathrm{c}$ \\
TWC & $8.61 \pm 0.17 \mathrm{a}$ & $7.54 \pm 0.17 \mathrm{~b}$ & $3.6 \pm 0.25 \mathrm{c}$ & $3.3 \pm 0.3 \mathrm{c}$ \\
Jandaroi & & & & \\
SL & $24.2 \pm 0.93 \mathrm{a}$ & $17 \pm 0.58 \mathrm{~b}$ & $16.5 \pm 1.26 \mathrm{~b}$ & $14.8 \pm 1.74 \mathrm{~b}$ \\
LA & $517 \pm 24 \mathrm{a}$ & $260 \pm 8 \mathrm{~b}$ & $180.1 \pm 28 \mathrm{c}$ & $165.4 \pm 12 \mathrm{c}$ \\
SDW & $0.128 \pm 0.007 \mathrm{a}$ & $0.046 \pm 0.004 \mathrm{~b}$ & $0.032 \pm 0.003 \mathrm{c}$ & $0.029 \pm 0.005 \mathrm{c}$ \\
RDW & $0.152 \pm 0.011 \mathrm{a}$ & $0.066 \pm 0.001 \mathrm{~b}$ & $0.044 \pm 0.002 \mathrm{c}$ & $0.040 \pm 0.007 \mathrm{c}$ \\
RDW: SDW & $1.18 \pm 0.03 \mathrm{~b}$ & $1.42 \pm 0.02 \mathrm{a}$ & $1.40 \pm 0.02 \mathrm{a}$ & $1.38 \pm 0.04 \mathrm{a}$ \\
CCI & $42.37 \pm 0.68 \mathrm{a}$ & $28 \pm 2.89 \mathrm{~b}$ & $27.1 \pm 1.91 \mathrm{~b}$ & $24 \pm 2.95 \mathrm{~b}$ \\
TWC & $7.6 \pm 0.17 \mathrm{a}$ & $5.4 \pm 0.33 \mathrm{~b}$ & $4.96 \pm 0.3 \mathrm{~b} \mathrm{c}$ & $4 \pm 0.13 \mathrm{c}$ \\
\hline
\end{tabular}

Value are the means \pm standard error of three replicates (nine plants). Mean values for each parameter sharing the same letter are not significantly different $(p \leq 0.05)$

The three treatments significantly reduced shoot dry weights in both cultivars. The effect of low $\mathrm{P}$ was similar in both cultivars, while salinity had a more pronounced effect in Jandaroi. The three treatments significantly $(p \leq 0.001)$ reduced root dry weights in both cultivars, more so in the low $\mathrm{P}$ and salinity + low $\mathrm{P}$ treatments. There was not much difference in both cultivars regarding their response to the combined treatment of salinity, and low $\mathrm{P}$ and reduction in dry weights was on par with low P treatments in both cultivars (Table 1). Root-to-shoot dry weight ratio (root:shoot) was higher in both low P treatments than in salinity and control treatments in Janz. In the case of Jandaroi, root:shoot in three stress treatments was on par and higher than the control treatment (Table 1).

Tissue water content (TWC) in both cultivars significantly declined in all three treatments (Table 1). In Janz, low P supply reduced TWC more than salinity. In Jandaroi, the reduction in TWC in low $\mathrm{P}$ treatment was on par with salinity and salinity + low P treatments. In both cultivars, the salinity + low P treatment reduced TWC to a similar level as the low P treatment. In Janz, the salinity treatment had no effect on the chlorophyll content index (Table 1), but it declined markedly in the low $\mathrm{P}$ and salinity + low $\mathrm{P}$ treatments. In Jandaroi, all three treatments reduced the chlorophyll content index to similar values, which were significantly less than the control.

The leaf gas exchange attributes were significantly $(p \leq 0.001)$ reduced under salinity and low $\mathrm{P}$ treatments. In both cultivars, leaf net photosynthetic rate (A) declined with salinity and low P supply, more so in the low $\mathrm{P}$ and salinity + low $\mathrm{P}$ treatments, which declined to similar values (Figure $1 \mathrm{~A}$ ). A similar trend was observed for transpiration rate (E) in Janz, while in Jandaroi transpiration rate declined but to a similar extent in all treatments (Figure 1B). In both cultivars, stomatal conductance declined more with low $\mathrm{P}$ supply than with soil salinity, and the reduction in the salinity + low $\mathrm{P}$ treatment was similar to that in the low P treatment (Figure 1C). 

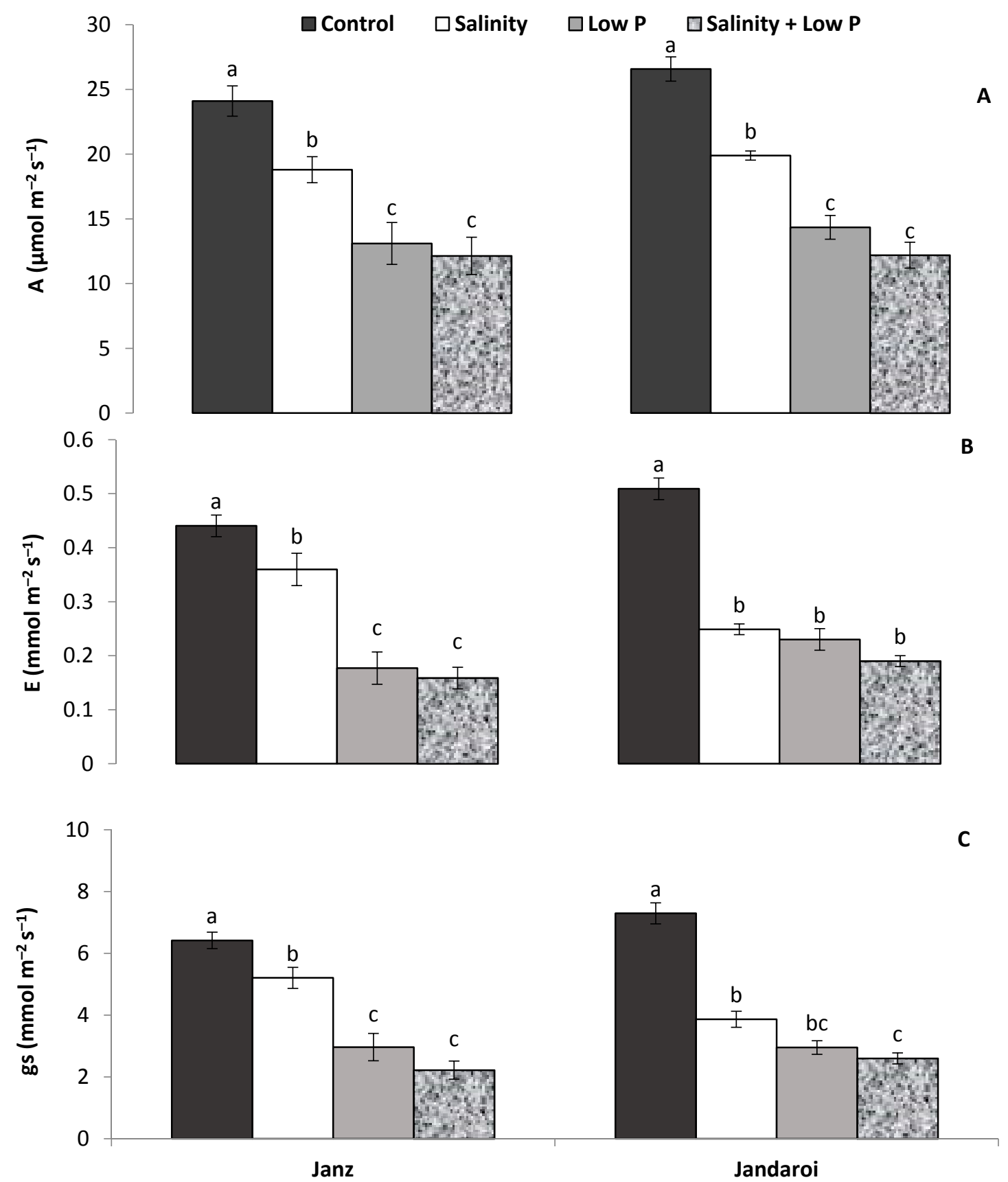

Figure 1. Effects of salinity, low $\mathrm{P}$ supply and their interaction on (A) net photosynthetic rate, (B) transpiration rate and (C) stomatal conductance in salt-tolerant (Janz) and salt-sensitive (Jandaroi) wheat cultivars. Values are the means \pm SE of three replicates (nine plants). For each cultivar, values sharing the same letter are not significantly different $(p \leq 0.05)$.

\subsection{Tissue Ionic Contents}

Shoot and root $\mathrm{Na}^{+}$concentrations increased significantly $(p \leq 0.001)$ in both cultivars in the salinity treatment (Table 2) and more so than the salinity + low $\mathrm{P}$ treatment. The low $\mathrm{P}$ treatment had no effect on shoot and root $\mathrm{Na}^{+}$concentration in either cultivar. Shoot and root $\mathrm{K}^{+}$concentrations decreased significantly $(p \leq 0.001)$ in both cultivars in all three treatments (Table 2$)$. The salinity treatment reduced the shoot and root $\mathrm{K}^{+}$concentrations more than the low $\mathrm{P}$ treatment in both cultivars. In the salinity + low P supply treatment, these reductions were similar to those in the salinity treatment, except for shoot $\mathrm{K}^{+}$concentration in Jandaroi, where an additive effect was observed. 
Table 2. Effects of salinity and low $\mathrm{P}$ supply, and their interactions on shoot and root ionic concentrations (mmol g ${ }^{-1} \mathrm{DW}$ ) and $\mathrm{K}: \mathrm{Na}$ ratios of salt-tolerant (Janz) and salt-sensitive (Jandaroi) wheat cultivars.

\begin{tabular}{ccccc}
\hline Janz & Control & Salinity & Low P & Salinity + Low P \\
\hline Shoot Na & $0.05 \pm 0.01 \mathrm{c}$ & $0.65 \pm 0.08 \mathrm{a}$ & $0.05 \pm 0.02 \mathrm{c}$ & $0.28 \pm 0.08 \mathrm{~b}$ \\
Shoot $\mathrm{K}$ & $0.68 \pm 0.06 \mathrm{a}$ & $0.45 \pm 0.04 \mathrm{c}$ & $0.57 \pm 0.03 \mathrm{~b}$ & $0.41 \pm 0.04 \mathrm{c}$ \\
Shoot $\mathrm{P}$ & $0.08 \pm 0.003 \mathrm{a}$ & $0.06 \pm 0.004 \mathrm{~b}$ & $0.02 \pm 0.001 \mathrm{c}$ & $0.01 \pm 0.005 \mathrm{c}$ \\
Root $\mathrm{Na}$ & $0.04 \pm 0.02 \mathrm{c}$ & $0.34 \pm 0.04 \mathrm{a}$ & $0.04 \pm 0.01 \mathrm{c}$ & $0.20 \pm 0.02 \mathrm{~b}$ \\
Root $\mathrm{K}$ & $0.47 \pm 0.03 \mathrm{a}$ & $0.22 \pm 0.03 \mathrm{c}$ & $0.31 \pm 0.01 \mathrm{~b}$ & $0.15 \pm 0.04 \mathrm{c}$ \\
Root $\mathrm{P}$ & $0.034 \pm 0.001 \mathrm{a}$ & $0.026 \pm 0.002 \mathrm{~b}$ & $0.012 \pm 0.000 \mathrm{c}$ & $0.014 \pm 0.002 \mathrm{c}$ \\
Shoot K: $\mathrm{Na}$ & $13.6 \pm 0.60 \mathrm{a}$ & $0.69 \pm 0.30 \mathrm{c}$ & $11.4 \pm 0.40 \mathrm{~b}$ & $1.48 \pm 0.60 \mathrm{c}$ \\
Root K: Na & $11.64 \pm 0.60 \mathrm{a}$ & $0.63 \pm 0.30 \mathrm{c}$ & $8.43 \pm 0.80 \mathrm{~b}$ & $0.74 \pm 0.40 \mathrm{c}$ \\
Jandaroi & & & & \\
Shoot Na & $0.08 \pm 0.01 \mathrm{c}$ & $0.93 \pm 0.09 \mathrm{a}$ & $0.09 \pm 0.01 \mathrm{c}$ & $0.66 \pm 0.07 \mathrm{~b}$ \\
Shoot K & $0.72 \pm 0.03 \mathrm{a}$ & $0.38 \pm 0.03 \mathrm{c}$ & $0.60 \pm 0.04 \mathrm{~b}$ & $0.20 \pm 0.03 \mathrm{~d}$ \\
Shoot $\mathrm{P}$ & $0.06 \pm 0.002 \mathrm{a}$ & $0.05 \pm 0.001 \mathrm{~b}$ & $0.02 \pm 0.002 \mathrm{c}$ & $0.02 \pm 0.004 \mathrm{c}$ \\
Root Na & $0.05 \pm 0.02 \mathrm{c}$ & $0.36 \pm 0.02 \mathrm{a}$ & $0.05 \pm 0.01 \mathrm{c}$ & $0.23 \pm 0.03 \mathrm{~b}$ \\
Root K & $0.45 \pm 0.05 \mathrm{a}$ & $0.16 \pm 0.01 \mathrm{c}$ & $0.29 \pm 0.02 \mathrm{~b}$ & $0.13 \pm 0.04 \mathrm{c}$ \\
Root $\mathrm{P}$ & $0.029 \pm 0.002 \mathrm{a}$ & $0.019 \pm 0.001 \mathrm{~b}$ & $0.012 \pm 0.001 \mathrm{c}$ & $0.013 \pm 0.002 \mathrm{c}$ \\
Shoot K: $\mathrm{Na}$ & $9.02 \pm 0.90 \mathrm{a}$ & $0.41 \pm 0.20 \mathrm{c}$ & $6.67 \pm 0.80 \mathrm{~b}$ & $0.30 \pm 0.10 \mathrm{c}$ \\
Root K: $\mathrm{Na}$ & $8.99 \pm 0.40 \mathrm{a}$ & $0.44 \pm 0.20 \mathrm{c}$ & $5.75 \pm 0.60 \mathrm{~b}$ & $0.57 \pm 0.30 \mathrm{c}$ \\
\hline
\end{tabular}

Value are means \pm standard error of three replicates (nine plants). Mean values for each parameter sharing the same letter are not significantly different $(p \leq 0.05)$

The shoot and root $\mathrm{K}^{+}: \mathrm{Na}^{+}$ratios decreased significantly $(p \leq 0.001)$ in both cultivars in the salinity and low $\mathrm{P}$ treatments (Table 2), more so in the salinity treatment. The $\mathrm{K}^{+}: \mathrm{Na}^{+}$ratios in both cultivars in the salinity + low $\mathrm{P}$ treatment declined to similar values as in the salinity treatment.

Shoot and root $\mathrm{P}$ concentrations declined $(p \leq 0.001)$ in both cultivars in the salinity and low $\mathrm{P}$ treatments (Table 2). The shoot and root $\mathrm{P}$ concentrations in both cultivars declined more, and to a similar extent, in the low $\mathrm{P}$ and salinity + low $\mathrm{P}$ treatments than the salinity treatment, more so in Janz than in Jandaroi.

\subsection{Root Growth}

From 10 to 20 DAS, there was no significant difference in accumulated root length between treatments in Janz (Figure 2A); differences became apparent from 30 DAS and maximal at 40 DAS, at which time the low $\mathrm{P}$ and salinity + low $\mathrm{P}$ treatments had the lowest accumulated root lengths. For Jandaroi, differences in accumulated root length between control and rest of the treatments became apparent as early as 20 DAS (Figure 2B). The largest differences were observed at 40 DAS with accumulated root length ranked as control $>$ salinity $>$ low P $>$ salinity + low P. From 10 to 20 DAS, all treatments had similar cumulative root numbers in Janz (Figure 2C); differences became apparent at 30 DAS and maximal at 40 DAS. For Jandaroi, differences in cumulative root numbers between control and rest of the treatments became apparent at 20 DAS (10 days early than Janz) though not statistically significant, and maximal at 40 DAS, at which time all treatments had the highest cumulative root numbers (Figure 2D). 


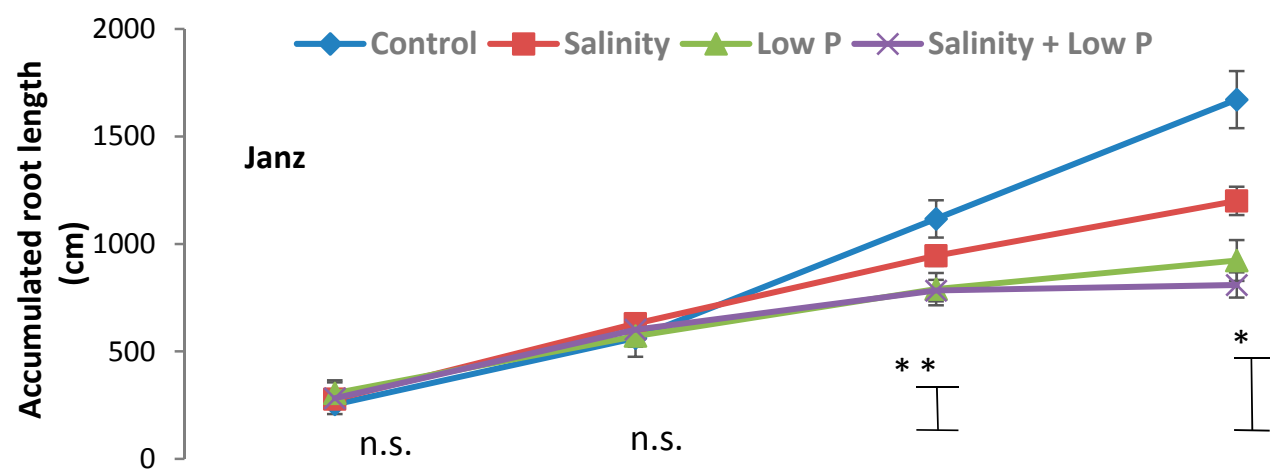

A

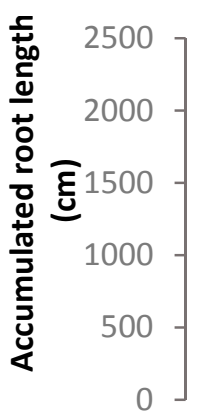

Jandaroi

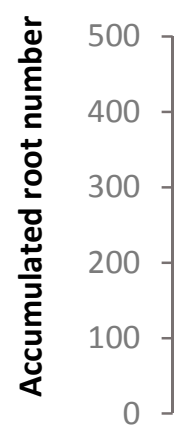

Janz

n.s.

n.s.

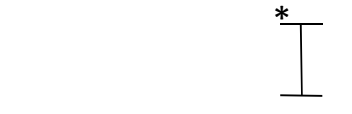

B

C

n.s.

n.s.
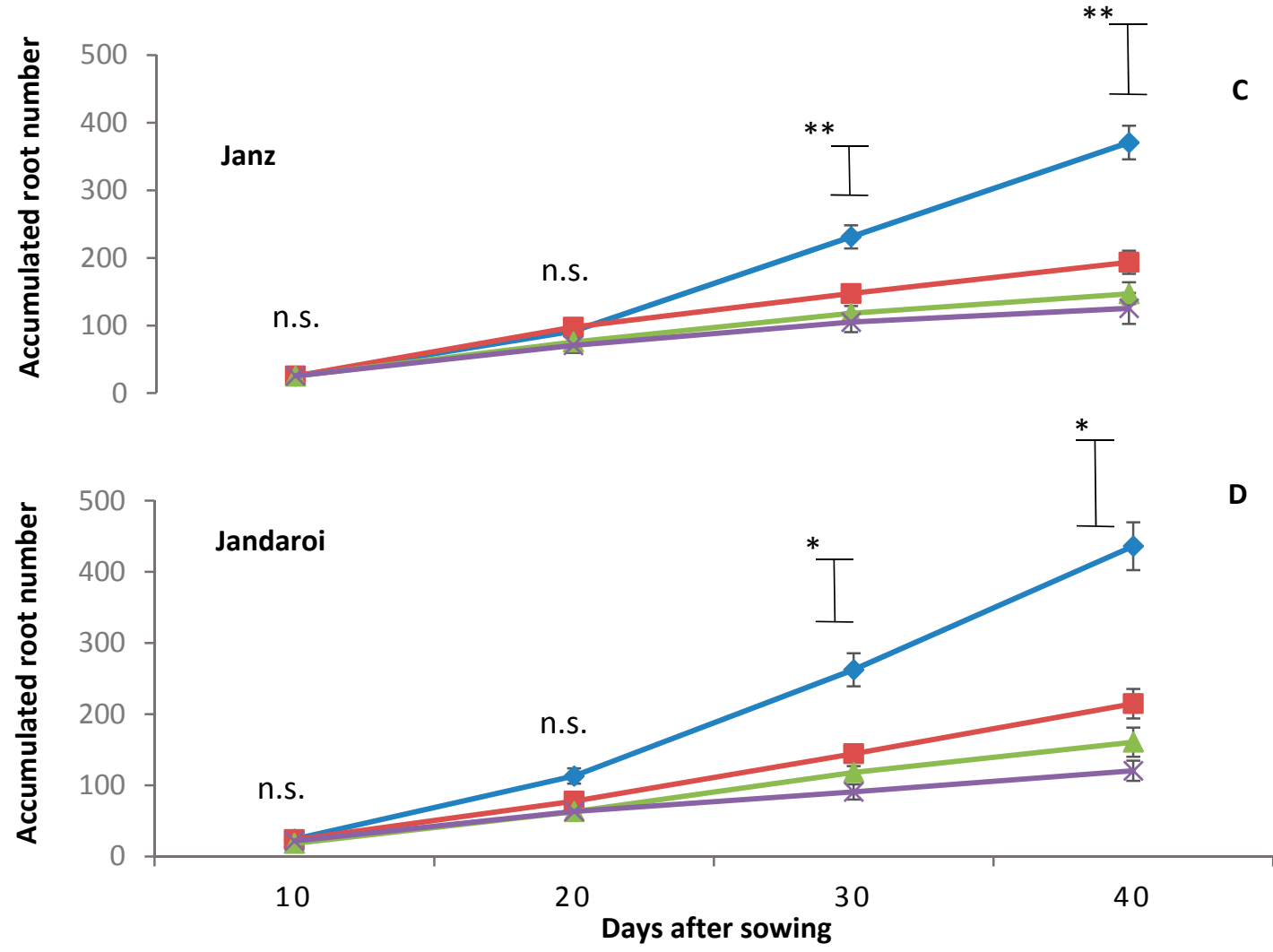

Figure 2. Changes in accumulated root length (A,B) and accumulated root number $(\mathbf{C}, \mathbf{D})$ with time in salt-tolerant (Janz) and salt-sensitive (Jandaroi) wheat cultivars in response to salinity, low P supply and their interaction. Measurements were made by root mapping at 10-day intervals from 10 DAS. Values are the means $\pm \mathrm{SE}$ of three replicates (nine plants). The vertical bars represent the least significant difference value at $p=0.05^{*}, p=0.001 * *$, and n.s., non-significant. 
Root length density (RLD) in both cultivars was higher in the top $10 \mathrm{~cm}$ layer of the soil profile than the middle $(10-20 \mathrm{~cm})$ and lower $(20-30 \mathrm{~cm}$ ) layers (Figure 3A,B), with RLD in top $10 \mathrm{~cm}$ layer ranked as control $>$ salinity $>$ low P > salinity + low P. In Janz, RLD in the middle layer did not differ between treatments, and no root growth occurred in the lower layer in the control. In Jandaroi, the control had higher RLD in the middle layer than the low P and salinity + low P treatments; no root growth occurred in the lower layer of the soil profile in the control or salinity treatment. Root number density (RND) in both cultivars was higher in the top layer of the soil profile than the middle and lower layers (Figure 3C,D). In both cultivars, the top layer had the highest RND (control > salinity $>$ low $\mathrm{P}>$ salinity + low P). In Janz, in the lower layer, the salinity treatment had higher RND than the two low P treatments. In Jandaroi, in the lower layer, there was no difference in RND between treatments.

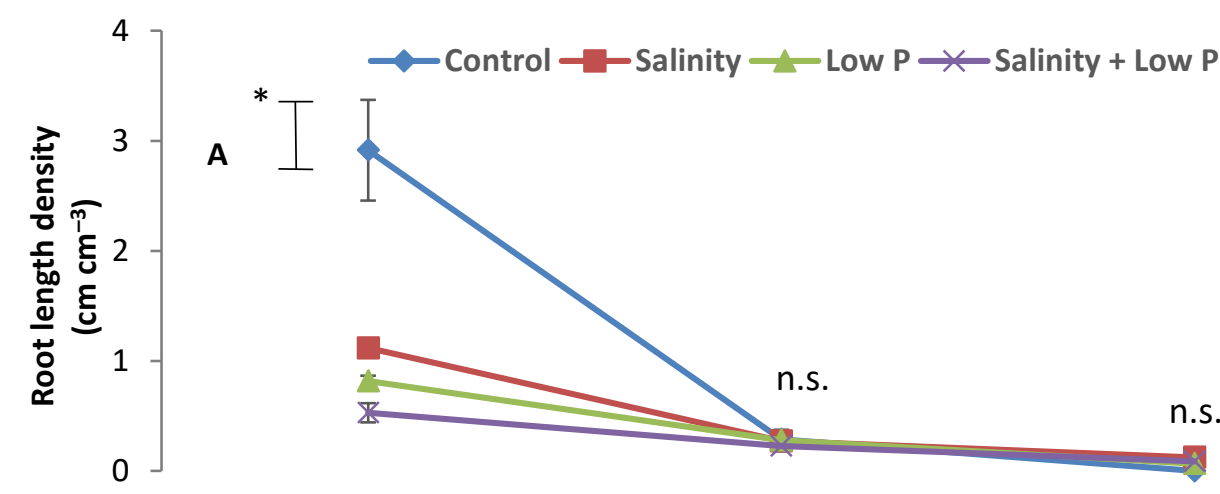

Janz

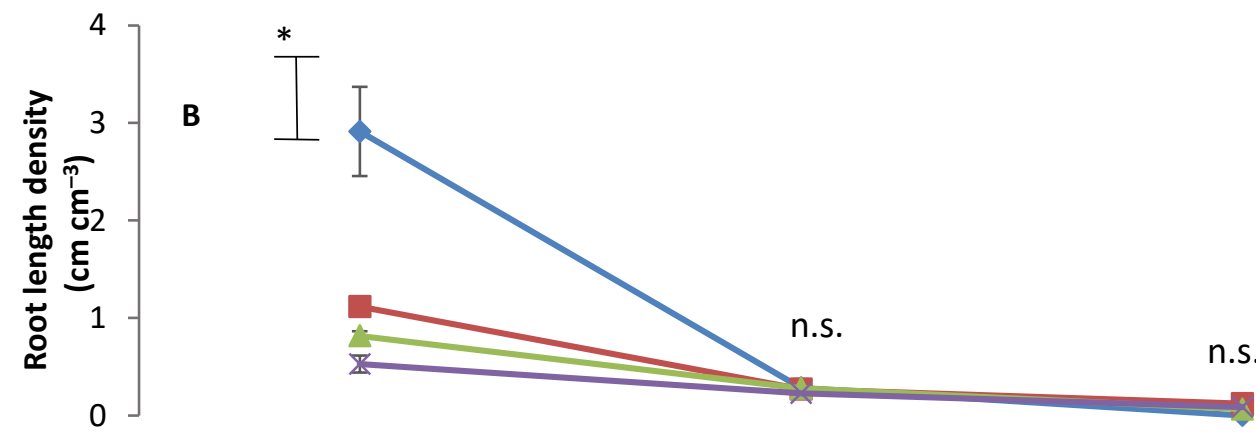

Jandaroi
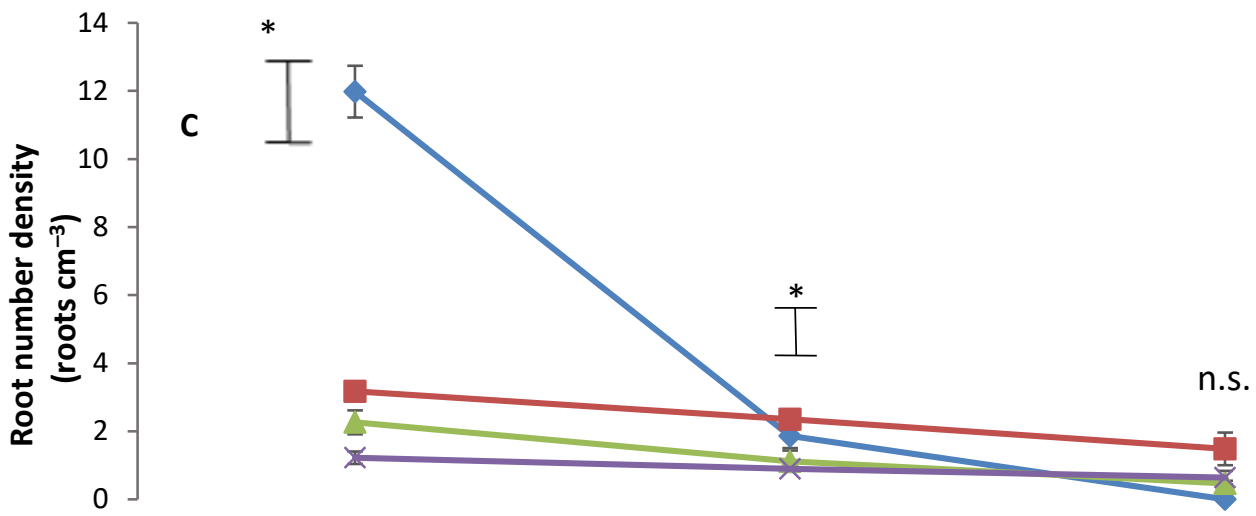

Janz

Figure 3. Cont. 


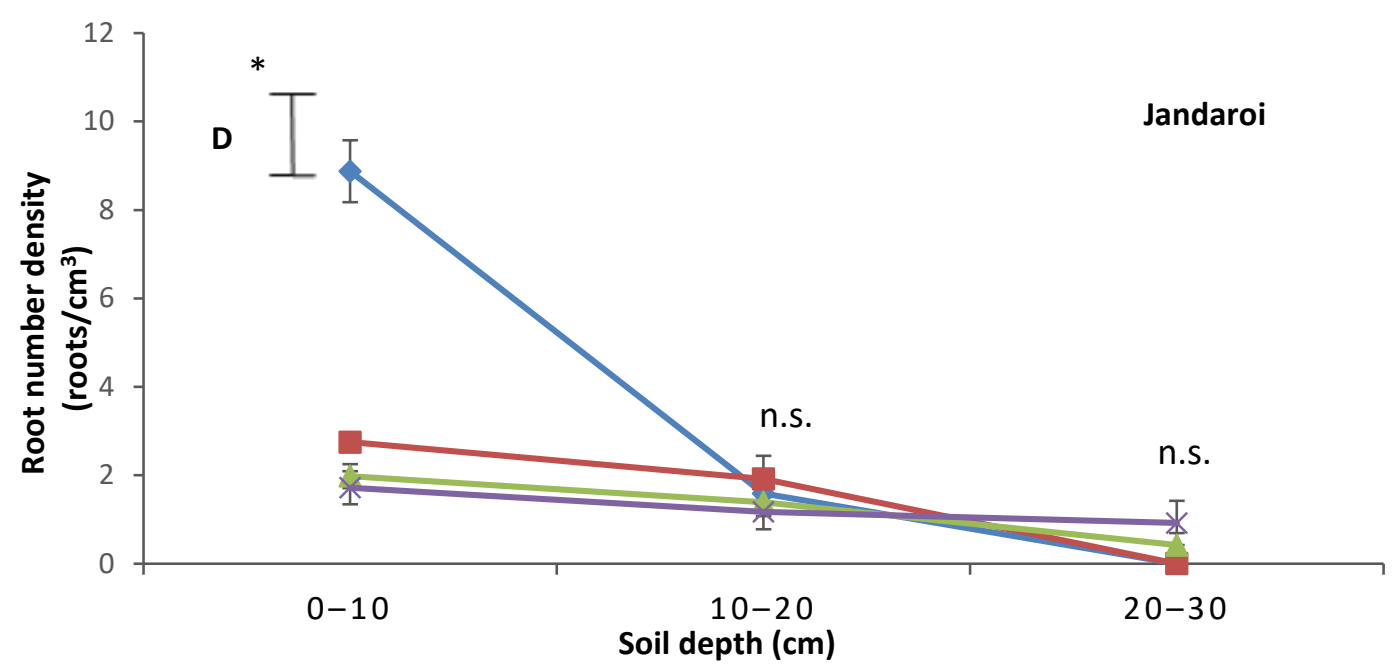

Figure 3. Changes in $(\mathbf{A}, \mathbf{B})$ root length density and $(\mathbf{C}, \mathbf{D})$ root number density with soil depth in salt-tolerant (Janz) and salt-sensitive (Jandaroi) wheat cultivars in response to salinity, low P supply, and their interaction. Measurements were made at the end of the experiment (40 DAS). Values are the means \pm SE of three replicates (nine plants). The vertical bars represent the least significant difference value at $p=0.05^{*}$ and n.s., non-significant.

At the end of the experiment (40 DAS), the three treatments had significantly $(p \leq 0.001)$ affected total root lengths and root numbers in both cultivars (Figures 4 and $5 \mathrm{~A}, \mathrm{~B}$ ). The controls had the highest total root lengths and root numbers, followed by the salinity treatment and, lastly, the two low $\mathrm{P}$ supply treatments. In both cultivars, the two low P treatments led to similar total root lengths and root numbers. Specific root length was higher in the three stress treatments as compared to control in Janz, whereas in the case of Jandaroi, control and salinity treatments had higher specific root lengths than the two low P treatments (Figure 5C).

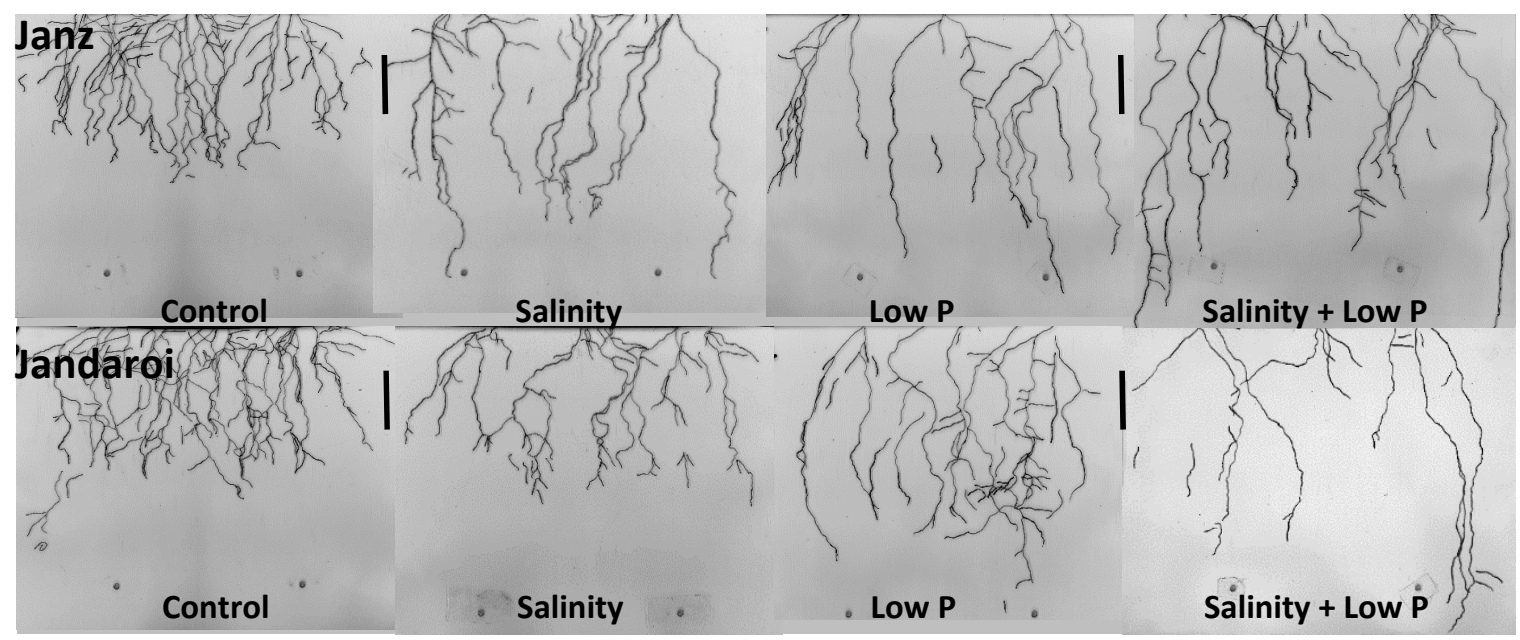

Figure 4. Scanned root images from the drawing at the end of the experiment (40 DAS) showing variations in root length and depth between the salt-tolerant (Janz) and salt-sensitive (Jandaroi) wheat cultivars in response to salinity, low P supply and their interaction. Bar $=5 \mathrm{~cm}$. 


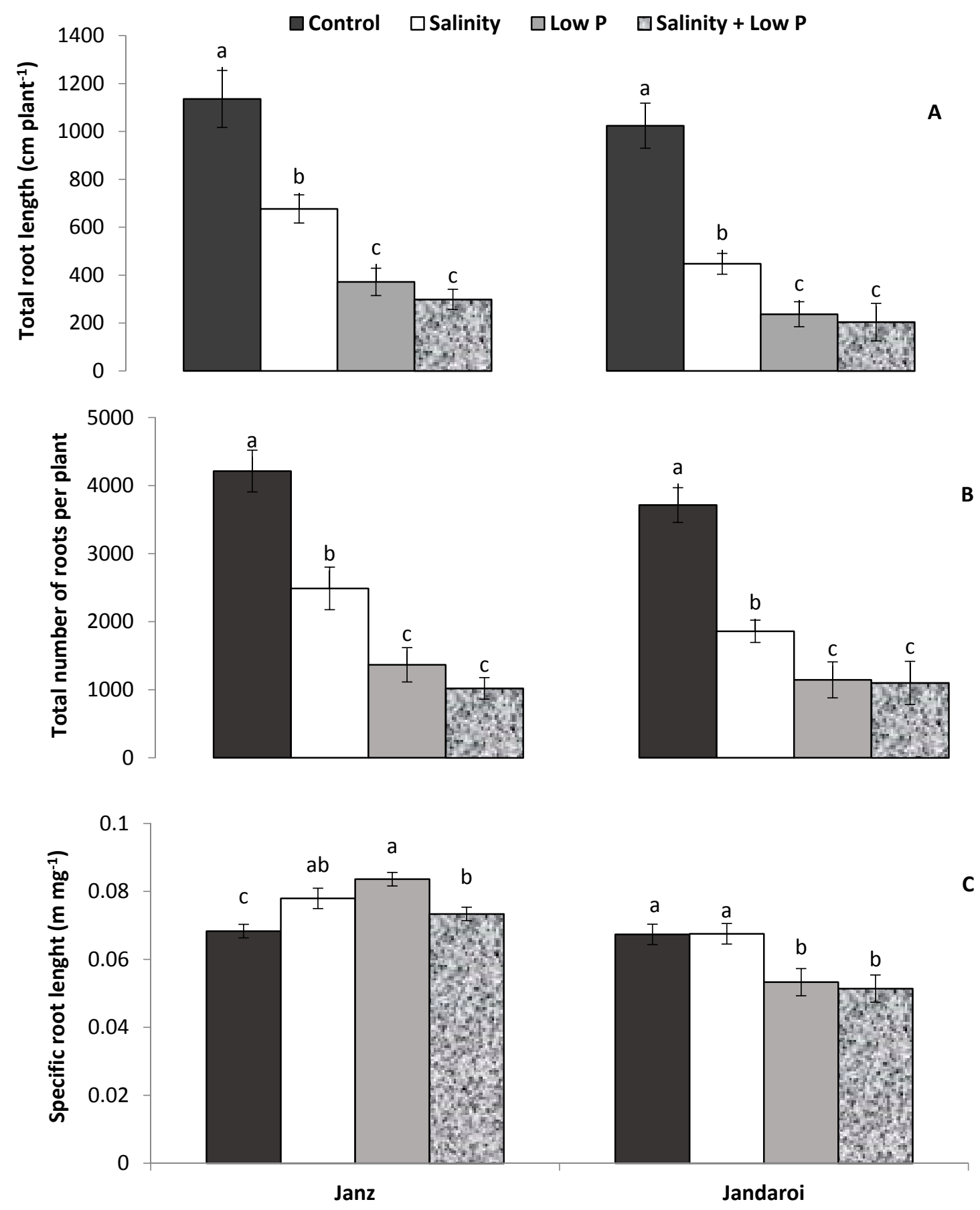

Figure 5. Effects of salinity, low $P$ supply and their interaction on (A) total root length (B), total root number, and (C) specific root length of salt-tolerant (Janz) and salt-sensitive (Jandaroi) wheat cultivars. Measurements were made at the end of the experiment (40 DAS). Values are the means \pm SE of three replicates (nine plants). For each cultivar, values sharing the same letter are not significantly different $(p \leq 0.05)$.

\section{Discussion}

\subsection{Relative Effect of P and Salt on Growth and Physiology}

This study found that low P stress $(10 \mu \mathrm{M})$ reduced the shoot and root growth of both wheat cultivars more than did salinity stress $(100 \mathrm{mM})$. In line with our findings, Talbi et al. [9] found that 
low P supply was the most limiting factor for barley growth when it was exposed to a combination of salinity and low P supply. Phosphorus is a crucial macronutrient that is involved in photosynthesis, carbohydrate metabolism, respiration, nucleic acid synthesis, membrane synthesis and stability, and enzymes activities [14,15]. Reductions in plant growth under salinity and/or low P supply has been well documented [9-11,16,41]. However, under low P supply, the addition of salt to the growth medium did not further reduce growth attributes in either cultivar; that is, the interactive effects were not additive. A hydroponic experiment found that $\mathrm{P}$ deficiency $(5 \mu \mathrm{M})$ significantly improved plant tolerance to salinity $(100 \mathrm{mM} \mathrm{NaCl})$ in a maize cultivar by regulating plant growth, tissue osmotic properties, and $\mathrm{K}^{+}$and $\mathrm{Na}^{+}$accumulation [42]. Other studies have suggested that the outcome of such interactions is related to plant species, cultivars, and the type of stress imposed $[10,13,23]$. Different levels of P in P deficiency studies have been used. For instance, Liao et al. [29] used 26 and $339 \mathrm{mg} \mathrm{P} / \mathrm{kg}$ soil as deficient and sufficient P levels, respectively, on cereals including wheat. In another study, Osborne et al. [28] grew 53 wheat genotypes at $0 \mathrm{~kg} / \mathrm{ha}$ and $30 \mathrm{~kg} / \mathrm{ha} P$ under field conditions, and Fahad et al. [13] applied $5 \mu \mathrm{M}$ P as a low P treatment, and $60 \mu \mathrm{M}$ P and $180 \mu \mathrm{M} \mathrm{P}$ as sufficient $P$ treatments to wild and cultivated barley. On the hand, screening/response of wheat genotypes to salinity has been mostly studied in the range of $50-150 \mathrm{mM} \mathrm{NaCl}[6,7,43]$. Regarding the interaction of salinity and low $\mathrm{P}$, our results are well in line with the findings of $[9,13,23]$ who applied $5 \mu \mathrm{M} \mathrm{P}$ as a low P treatment, and $100 \mathrm{mM} \mathrm{NaCl}$ as salinity stress. The results clearly showed a stronger effect of low $\mathrm{P}$ than the applied level of salinity. So, for more conclusive studies of interaction between low $\mathrm{P}$ and salinity stress, gradients of stress levels of low $\mathrm{P}$ and $\mathrm{NaCl}$ should be applied.

In this study, as expected, the salinity treatment affected the salt-sensitive Jandaroi more than the salt-tolerant Janz, confirming the greater salt tolerance potential of the later cultivar [27,34]. The more severe osmotic [5] and ionic [6,44] effects of salts in Jandaroi are likely to have resulted in the greater reductions in shoot and root biomass, relative to Janz. The osmotic effect is the first response to salinity and it reduces growth, mainly due to water deficiency in the plant tissues. The ionic effect is characterized by excessive accumulation of toxic ions in the cells, which slows growth by interfering with some important biochemical processes [5]. In contrast to saline treatment, there was not much difference in both cultivars regarding their response to low $\mathrm{P}$ and the combined treatment of salinity with low P. Both Janz [28-30] and Jandaroi [31,32] are P-inefficient cultivars. Their similar sensitivities to $\mathrm{P}$ might be one of the factors for their similar dry weight productions under both low $\mathrm{P}$ treatments. The greater reduction in biomass under low $\mathrm{P}$ than salinity may be related to the greater reduction of various physiological attributes, such as tissue water and chlorophyll contents and gas exchange parameters. Under P-deficient conditions, the water-conducting capacity of roots declines, due to the reduced activity of water channel proteins (aquaporins), which ultimately reduces cell water contents $[9,23,45]$. The leaf chlorophyll content in both cultivars decreased under low P supply, which agrees with the findings from previous studies [46], and may be due to its limited biosynthesis or enhanced degradation through increased activity of the chlorophyllase enzyme [47]. It is important to note that the salinity treatment did not affect chlorophyll content in Janz, again confirming its greater salt tolerance.

Leaf gas exchange attributes (net photosynthesis rate, stomatal conductance and transpiration rate) in both cultivars were affected to different extents by soil salinity and low P supply, as observed in previous studies $[9,23]$. Leaf gas exchange characteristics did not significantly differ between the low $\mathrm{P}$ and the salinity + low $\mathrm{P}$ treatments in either cultivar. Reduced stomatal conductance under salinity and/or low P stress limits $\mathrm{CO}_{2}$ influx and water vapor efflux from the leaf surface $[9,48]$. In our study, the limited intake of $\mathrm{CO}_{2}$ and the reduced chlorophyll contents may have caused the apparent reduction in photosynthetic rate in both cultivars. However, Yousfi et al. [49] reported that stomatal closure is an adaptive mechanism by plants suffering from salinity-induced water deficiency, and it causes a corresponding decrease in transpiration rate. A reduction in gas exchange attributes can greatly influence biomass production [50]. In our study, the low $\mathrm{P}$ treatment reduced gas exchange attributes more than did the salinity treatment, thus further reducing plant biomass in both cultivars. 


\subsection{Relative Effects of $P$ and Salt on Ionic Balance}

We found that $\mathrm{Na}^{+}$accumulation was higher in saline treatment with optimal $\mathrm{P}$ supply than low P supply, which has also been observed in barley [9]. In soybean, high P supply increased $\mathrm{Na}^{+}$uptake, reducing salt tolerance [24]. It can thus be concluded that $\mathrm{P}$ supply affects $\mathrm{Na}^{+}$transport within plants. A recent study in maize showed that $P$ deficit improved plant tolerance to salinity stress by reducing tissue $\mathrm{Na}^{+}$accumulation [42]. Under both salinity treatments, bread wheat cultivar Janz accumulated significantly less $\mathrm{Na}^{+}$in shoot as compared to the durum wheat cultivar Jandaroi. This differential $\mathrm{Na}^{+}$uptake may be related to the presence of HKT1; 5 transporter on the Kna1 locus on chromosome $4 \mathrm{D}$, in case of the hexaploid wheat Janz, and it is absent in tetraploid wheat (Jandaroi) [51]. We found that the salinity treatment reduced shoot and root $\mathrm{K}^{+}$concentrations more than the low $\mathrm{P}$ treatment, in line with previous studies $[9,23]$. The greater reduction in $\mathrm{K}^{+}$concentration under salinity is due to competition between $\mathrm{Na}^{+}$and $\mathrm{K}^{+}$ions for the same cation channels, and the limited uptake of $\mathrm{K}^{+}$in the presence of a higher concentration of $\mathrm{Na}^{+}$ions in the growth medium [10,52] resulting in lower $\mathrm{K}^{+}: \mathrm{Na}^{+}$ratios. Therefore, the higher salinity tolerance of Janz compared to Jandaroi may be attributed to (a) its relatively higher shoot and root $\mathrm{K}$ uptake, (b) higher $\mathrm{K}^{+}: \mathrm{Na}^{+}$ratios, and (c) $\mathrm{Na}^{+}$exclusion from shoot via the HKT1;5 transporter [3,6,51,53].

We found that low $\mathrm{P}$ supply in the growth medium caused remarkable decreases in shoot and root $P$ concentrations in both cultivars as also observed by $[13,16]$. Salinity also caused significant declines in shoot and root $P$ concentrations, which contrasts with the findings of $[13,23]$, where shoot and root $\mathrm{P}$ concentrations increased in barley grass and cultivated barley genotypes in response to salinity. However, in studies on lettuce [21] and spinach [22], soil salinity reduced P concentrations in all plant tissues. Information on the interaction of salinity and low P is limited and without consensus [25]. It has been suggested that the effects of salinity on P uptake vary depending on growth conditions (sand culture, soil culture, or hydroponics), the amount of salt and $\mathrm{P}$ in the media, the duration of the treatments, and the species or genotypes being tested [54].

\subsection{Relative Effects of P and Salt on Root Growth and Morphology}

Our data on accumulated root lengths and numbers revealed that the growth pattern of the two wheat cultivars differed with time. Both cultivars had similar accumulated root lengths and numbers for all the treatments at 10 DAS. The differences between the control and the rest of the treatments in Jandaroi became apparent as early as 20 DAS, whereas in case of Janz, these differences became apparent only at 30 DAS. For both cultivars, more clear differences in root lengths and root numbers between the control and the stress treatments were observed at 40 DAS than at 20 and 30 DAS. Similar root growth and proliferation patterns with time has been well documented for various wheat cultivars under different treatments [30,35,36]. Moreover [1] reported that the initial effect of salinity (osmotic effect) becomes effective with the addition of salt, and causes early growth reduction in plants due to water deficiency. Nevertheless, this osmotic effect is a temporary stress and it is followed by a more pronounced and deleterious ionic effect if plants are exposed to salinity for a few weeks.

Root length and root number densities in both cultivars were higher in the upper soil layers $(0-10 \mathrm{~cm})$ than the middle $(10-20 \mathrm{~cm})$ and lower $(20-30 \mathrm{~cm})$ layers. A similar pattern was observed in narrow-leafed lupin in P-deficient conditions [41]. Pfeifer et al. [36] observed similar root growth patterns in Janz and two other wheat genotypes. In the upper soil layer, the control treatment had the highest root length densities for both cultivars, followed by the salinity, low $\mathrm{P}$ and salinity + low $\mathrm{P}$ treatments. In the middle and lower soil layers, there were few differences between treatments. Root:shoot ratio was increased in both cultivars under $\mathrm{P}$ deficient conditions. This was mainly due to changes in biomass allocation pattern from shoot to root in response to low $\mathrm{P}$ supply $[9,13]$. Specific root length was higher in both low P treatments in Janz, whereas in Jandaroi, it was lower as compared to the control treatment. Specific root length is an indicator of root thickness [30]. Thus, it can be inferred that in response to low P supply, Jandaroi produced thicker roots and Janz produced more fine roots. While the highest total root length and root number for both cultivars were observed in the control 
treatment, root growth in deeper soil layers with low P supply may be due to the adaptive strategies of plants to increase P uptake [55]. For example, several authors have reported that the root morphology of plants shifts towards finer and longer roots under low $\mathrm{P}$ conditions to enhance P uptake from deeper soil layers $[13,16,43]$.

\section{Conclusions}

Our study has demonstrated that low $\mathrm{P}(10 \mu \mathrm{M} \mathrm{P})$ caused more reduction in shoot and root growth attributes than salinity $(100 \mathrm{mM} \mathrm{NaCl})$, both in salt-tolerant and salt-sensitive wheat cultivars. Cultivar Janz had lower tissue $\mathrm{Na}^{+}$accumulation and thus was more tolerant to salinity than Jandaroi. The detrimental effects of soil salinity and low $\mathrm{P}$ supply on root length and root number became apparent 10 days earlier in Jandaroi than Janz, and these effects were more pronounced in the top layer of soil profile in both cultivars.

Author Contributions: Conceptualization, G.A., J.A.P., and K.H.M.S.; Data curation, G.A., Y.C., F.Y.K., and Y.F.; Formal analysis, G.A. and Y.C.; Funding acquisition, K.H.M.S.; Investigation, G.A.; Methodology, G.A., Y.C., F.Y.K., and Y.F.; Resources, K.H.M.S.; Software, J.A.P.; Supervision, K.H.M.S.; Visualization, K.H.M.S.; Writing-original draft, G.A. and Y.C.; Writing-review \& editing, J.A.P. and K.H.M.S.

Funding: This research received no external funding.

Acknowledgments: This research was supported by The University of Western Australia (UWA) and an Australian Endeavour Research Fellowship awarded to GA. The Higher Education Commission of Pakistan and the China Scholarship Council provided financial support to FK and YF, respectively, for their training visits to UWA.

Conflicts of Interest: The authors declare no conflicts of interest for this particular research.

\section{References}

1. Munns, R.; Tester, M. Mechanisms of salinity tolerance. Annu. Rev. Plant Biol. 2008, 59, 651-681. [CrossRef] [PubMed]

2. Qadir, M.; Quillérou, E.; Nangia, V.; Murtaza, G.; Singh, M.; Thomas, R.J.; Drechsel, P.; Noble, A.D. Economics of salt-induced land degradation and restoration. In Natural Resources Forum; Wiley Online Library: Bognor Regis, UK, 2014; pp. 282-295.

3. Negrão, S.; Schmöckel, S.; Tester, M. Evaluating physiological responses of plants to salinity stress. Ann. Bot. 2017, 119, 1-11. [CrossRef] [PubMed]

4. Abbas, G.; Saqib, M.; Akhtar, J.; Murtaza, G. Physiological and biochemical characterization of Acacia stenophylla and Acacia albida exposed to salinity under hydroponic conditions. Can. J. For. Res. 2017, 47, 1293-1301. [CrossRef]

5. Flowers, T.J.; Colmer, T.D. Plant salt tolerance: Adaptations in halophytes. Ann. Bot. 2015, 115, 327-331. [CrossRef] [PubMed]

6. Saqib, M.; Zörb, C.; Rengel, Z.; Schubert, S. The expression of the endogenous vacuolar $\mathrm{Na}^{+} / \mathrm{H}^{+}$antiporters in roots and shoots correlates positively with the salt resistance of wheat (Triticum aestivum L.). Plant Sci. 2005, 169, 959-965. [CrossRef]

7. Saqib, M.; Akhtar, J.; Abbas, G.; Nasim, M. Salinity and drought interaction in wheat (Triticum aestivum L.) is affected by the genotype and plant growth stage. Acta Physiol. Plant. 2013, 35, 2761-2768. [CrossRef]

8. Hu, Y.; Hackl, H.; Schmidhalter, U. Comparative performance of spectral and thermographic properties of plants and physiological traits for phenotyping salinity tolerance of wheat cultivars under simulated field conditions. Funct. Plant Biol. 2017, 44, 134-142. [CrossRef]

9. Talbi, Z.O.; Abdelly, C.; Debez, A. Interactive effects of salinity and phosphorus availability on growth, water relations, nutritional status and photosynthetic activity of barley (Hordeum vulgare L.). Plant Biol. 2011, 13, 872-880. [CrossRef] [PubMed]

10. Abbas, G.; Saqib, M.; Akhtar, J. Interactive effects of salinity and iron deficiency on different rice genotypes. J. Plant Nutr. Soil Sci. 2015, 178, 306-311. [CrossRef]

11. Rahnama, A.; Munns, R.; Poustini, K.; Watt, M. A screening method to identify genetic variation in root growth response to a salinity gradient. J. Exp. Bot. 2011, 62, 69-77. [CrossRef] [PubMed] 
12. Zribi, O.T.; Houmani, H.; Kouas, S.; Slama, I.; Ksouri, R.; Abdelly, C. Comparative study of the interactive effects of salinity and phosphorus availability in wild (Hordeum maritimum) and cultivated barley (H. vulgare). J. Plant Growth Regul. 2014, 33, 860-870. [CrossRef]

13. Fahad, S.; Hussain, S.; Saud, S.; Hassan, S.; Tanveer, M.; Ihsan, M.Z.; Shah, A.N.; Ullah, A.; Khan, F.; Ullah, S.; et al. A combined application of biochar and phosphorus alleviates heat-induced adversities on physiological, agronomical and quality attributes of rice. Plant Physiol. Biochem. 2016, 103, 191-198. [CrossRef] [PubMed]

14. Vance, C.P.; Uhde-Stone, C.; Allan, D.L. Phosphorus acquisition and use: Critical adaptations by plants for securing a nonrenewable resource. New Phytol. 2003, 157, 423-447. [CrossRef]

15. Chen, Y.L.; Dunbabin, V.M.; Diggle, A.J.; Siddique, K.H.; Rengel, Z. Phosphorus starvation boosts carboxylate secretion in P-deficient genotypes of Lupinus angustifolius with contrasting root structure. Crop Pasture Sci. 2013, 64, 588-599. [CrossRef]

16. Niu, Y.F.; Chai, R.S.; Jin, G.L.; Wang, H.; Tang, C.X.; Zhang, Y.S. Responses of root architecture development to low phosphorus availability: A review. Ann. Bot. 2012, 112, 391-408. [CrossRef] [PubMed]

17. Holford, I. Soil phosphorus: Its measurement, and its uptake by plants. Soil Res. 1997, 35, 227-240. [CrossRef]

18. Marschner, P.; Solaiman, Z.; Rengel, Z. Rhizosphere properties of Poaceae genotypes under P-limiting conditions. Plant Soil 2006, 283, 11-24. [CrossRef]

19. Qadir, M.; Noble, A.D.; Oster, J.; Schubert, S.; Ghafoor, A. Driving forces for sodium removal during phytoremediation of calcareous sodic and saline-sodic soils: A review. Soil Use Manag. 2005, 21, 173-180. [CrossRef]

20. Martinez, V.; Bernstein, N.; Läuchli, A. Salt-induced inhibition of phosphorus transport in lettuce plants. Physiol. Plant 1996, 97, 118-122. [CrossRef]

21. Kaya, C.; Higgs, D.; Kirnak, H. The effects of high salinity $(\mathrm{NaCl})$ and supplementary phosphorus and potassium on physiology and nutrition development of spinach. Bulg. J. Plant Physiol. 2001, 27, 47-59.

22. Zribi, O.T.; Labidi, N.; Slama, I.; Debez, A.; Ksouri, R.; Rabhi, M.; Smaoui, A.; Abdelly, C. Alleviation of phosphorus deficiency stress by moderate salinity in the halophyte Hordeum maritimum L. Plant Growth Regul. 2012, 66, 75-85. [CrossRef]

23. Phang, T.H.; Shao, G.; Liao, H.; Yan, X.; Lam, H.M. High external phosphate (Pi) increases sodium ion uptake and reduces salt tolerance of 'Pi-tolerant'soybean. Physiol. Plant. 2009, 135, 412-425. [CrossRef] [PubMed]

24. Hu, Y.; Schmidhalter, U. Drought and salinity: A comparison of their effects on mineral nutrition of plants. J. Plant Nutr. Soil Sci. 2005, 168, 541-549. [CrossRef]

25. Maas, E.V.; Hoffman, G.J. Crop salt tolerance-current assessment. J. Irrig. Drain. Div. 1977, 103, $115-134$.

26. Genc, Y.; Mcdonald, G.K.; Tester, M. Reassessment of tissue $\mathrm{Na}^{+}$concentration as a criterion for salinity tolerance in bread wheat. Plant Cell Environ. 2007, 30, 1486-1498. [CrossRef] [PubMed]

27. McDonald, G.; Bovill, W.; Taylor, J.; Wheeler, R. Responses to phosphorus among wheat genotypes. Crop Pasture Sci. 2015, 66, 430-444. [CrossRef]

28. Osborne, L.; Rengel, Z. Genotypic differences in wheat for uptake and utilisation of P from iron phosphate. Crop Pasture Sci. 2002, 53, 837-844. [CrossRef]

29. Liao, M.; Palta, J.A.; Fillery, I.R. Root characteristics of vigorous wheat improve early nitrogen uptake. Aust. J. Agric. Res. 2006, 57, 1097-1107. [CrossRef]

30. Zaicou, C.; Curtis, B.; Dhammu, H.; Ellis, S.; Jorgensen, D.; Miyan, S.; Penny, S.; Shackley, B.; Sharma, D. Wheat Variety Guide 2008 Western Australia; Department of Agriculture and Food (Western Australia): Perth, Australia, 2008.

31. Schwenke, G.; Simpfendorfer, S.; Collard, B. Confirmation of chloride deficiency as the cause of leaf spotting in durum wheat grown in the Australian northern grains region. Crop Pasture Sci. 2015, 66, 122-134. [CrossRef]

32. Shamaya, N.J. Genetic Studies of Salinity Tolerance in Wheat. Master's Thesis, The University of Adelaide, Adelaide, Australia, 2014.

33. Zhu, M.; Shabala, S.; Shabala, L.; Fan, Y.; Zhou, M. Evaluating predictive values of various physiological indices for salinity stress tolerance in wheat. J. Agron. Crop Sci. 2016, 202, 115-124. [CrossRef]

34. Aziz, M.M.; Palta, J.A.; Siddique, K.H.; Sadras, V.O. Five decades of selection for yield reduced root length density and increased nitrogen uptake per unit root length in Australian wheat varieties. Plant Soil 2017, 413, 181-192. [CrossRef] 
35. Palta, J.A.; Fillery, I.R.; Rebetzke, G.J. Restricted-tillering wheat does not lead to greater investment in roots and early nitrogen uptake. Field Crop. Res. 2007, 104, 52-59. [CrossRef]

36. Pfeifer, J. Elucidation of Root-Soil Interactions of Crops in Space and Time by Establishment and Application of Novel Image Based Non-Invasive Root Phenotyping Methods. Doctoral Thesis, ETH-Zürich, Zurich, Switzerland, 2013.

37. Basett, J.; Denney, R.; Jerrery, G.; Mendham, J. Vogel's Text Book of Quantitative Inorganic Analysis, 5th ed.; Longman Group: London, UK, 1978.

38. Chen, Y.L.; Dunbabin, V.M.; Diggle, A.J.; Siddique, K.H.; Rengel, Z. Assessing variability in root traits of wild Lupinus angustifolius germplasm: Basis for modelling root system structure. Plant Soil 2012, 354, 141-155. [CrossRef]

39. Steel, R.; Torrie, J.; Dickey, D. Principles and Procedures of Statistics: A Biometrical Approach, 3rd ed.; McGraw-Hill Book Co. Inc.: New York, NY, USA, 1997.

40. Chen, Y.L.; Dunbabin, V.M.; Postma, J.A.; Diggle, A.J.; Siddique, K.H.; Rengel, Z. Modelling root plasticity and response of narrow-leafed lupin to heterogeneous phosphorus supply. Plant Soil 2013, 372, 319-337. [CrossRef]

41. Wang, J.; Li, B.; Meng, Y.; Ma, X.; Lai, Y.; Si, E.; Yang, K.; Ren, P.; Shang, X.; Wang, H. Transcriptomic profiling of the salt-stress response in the halophyte Halogeton glomeratus. BMC Genom. 2015, 16, 169. [CrossRef] [PubMed]

42. Chen, Y.; (The University of Western Australia, Australia). Personal communication, 2017.

43. Munns, R.; James, R.A. Screening methods for salinity tolerance: A case study with tetraploid wheat. Plant Soil 2003, 253, 201-218. [CrossRef]

44. Li, J.; Xie, Y.; Dai, A.; Liu, L.; Li, Z. Root and shoot traits responses to phosphorus deficiency and QTL analysis at seedling stage using introgression lines of rice. J. Genet. Genom. 2009, 36, 173-183. [CrossRef]

45. Tewari, R.K.; Kumar, P.; Tewari, N.; Srivastava, S.; Sharma, P.N. Macronutrient deficiencies and differential antioxidant responses-Influence on the activity and expression of superoxide dismutase in maize. Plant Sci. 2004, 166, 687-694. [CrossRef]

46. Sultana, N.; Ikeda, T.; Itoh, R. Effect of $\mathrm{NaCl}$ salinity on photosynthesis and dry matter accumulation in developing rice grains. Environ. Exp. Bot. 1999, 42, 211-220. [CrossRef]

47. He, G.; Zhang, J.; Hu, X.; Wu, J. Effect of aluminum toxicity and phosphorus deficiency on the growth and photosynthesis of oil tea (Camellia oleifera Abel.) seedlings in acidic red soils. Acta Physiol. Plant. 2011, 33, 1285-1292. [CrossRef]

48. Koyro, H.-W. Effect of salinity on growth, photosynthesis, water relations and solute composition of the potential cash crop halophyte Plantago coronopus (L.). Environ. Exp. Bot. 2006, 56, 136-146. [CrossRef]

49. Yousfi, S.; Houmani, H.; Zribi, F.; Abdelly, C.; Gharsalli, M. Physiological responses of wild and cultivated barley to the interactive effect of salinity and iron deficiency. ISRN Agron. 2012. [CrossRef]

50. Gorham, J.; Jones, R.W.; Bristol, A. Partial characterization of the trait for enhanced $\mathrm{K}^{+}-\mathrm{Na}^{+}$discrimination in the D genome of wheat. Planta 1990, 180, 590-597. [CrossRef] [PubMed]

51. Byrt, C.S.; Xu, B.; Krishnan, M.; Lightfoot, D.J.; Athman, A.; Jacobs, A.K.; Watson-Haigh, N.S.; Plett, D.; Munns, R.; Tester, M.; et al. The $\mathrm{Na}^{+}$transporter, TaHKT1; 5-D, limits shoot $\mathrm{Na}^{+}$accumulation in bread wheat. Plant J. 2014, 80, 516-526. [CrossRef] [PubMed]

52. Grattan, S.; Grieve, C. Salinity-mineral nutrient relations in horticultural crops. Sci. Hortic. 1998, 78, $127-157$. [CrossRef]

53. Adams, E.; Shin, R. Transport, signaling, and homeostasis of potassium and sodium in plants. J. Integr. Plant Biol. 2014, 56, 231-249. [CrossRef] [PubMed]

54. Marschner, H. Mineral Nutrition of Higher Plants, 3rd ed.; Academic Press: London, UK, 1995.

55. Fujita, K.; Kai, Y.; Takayanagi, M.; El-Shemy, H.; Adu-Gyamfi, J.J.; Mohapatra, P.K. Genotypic variability of pigeonpea in distribution of photosynthetic carbon at low phosphorus level. Plant Sci. 2004, 166, 641-649. [CrossRef]

(C) 2018 by the authors. Licensee MDPI, Basel, Switzerland. This article is an open access article distributed under the terms and conditions of the Creative Commons Attribution (CC BY) license (http:/ / creativecommons.org/licenses/by/4.0/). 